\title{
The Role of Gender in Potato Production and Marketing: Case of Sheka Zone, Southwest Ethiopia
}

\author{
Fayera Bakala \\ Department of Natural Resource Management, Mizan- Tepi University \\ PO Box 260, Mizan Aman, Ethiopia
}

Tel: 251-979-731-175Ｅ-mail: feyebekele2014@gmail.com

Benyam Tadesse (Corresponding author)

Department of Agricultural Economics, Mizan- Tepi University

PO Box 260, Mizan Aman, Ethiopia

Tel: 251-935-938-317Ｅ-mail: tadessebenyam7@gmail.com

Received: April 20, 2018

doi:10.5296/wjbm.v4i2.13930
Accepted: June 8, 2018

Published: November 20, 2018

URL: https://doi.org/10.5296/wjbm.v4i2.13930

\begin{abstract}
The objective of the study was assessing gender roles in potato production and marketing in the study area. Relevant information was gathered from 193 potato producers by using primary and secondary sources of data. The data were analyzed by using descriptive statistics. The result indicated that in seed collection (46.3\%), land preparation (60.3\%), planting (96.8\%), weeding (50.3\%), cultivation (32.6\%), Harvesting (38\%), transporting (39.9\%) and marketing $(68.9 \%)$ of women respondents participate. Decisions about production and marketing of potato in the study area was mainly taken by men and in some cases, women participates. The main challenges that hinder gender participation in potato production and marketing was lack of access and control over assets(19.2\%), lack of control of income $(30.6 \%)$, Lack of land (6.7\%) and lack of decision making on potato production(39.9\%). Therefore, increasing opportunities for women, giving recognition, encouraging, documenting and disseminating their role can have a positive influence on productivity of potato.
\end{abstract}

Keywords: Decision making, Division of labour, Gender role, Gender, Potato marketing, Potato production, Sheka 


\section{Introduction}

Gender relates to socially assigned roles and behaviors attributable to men and women. Gender roles are roles that are played by both women and men and which are not determined by biological factors but by the socioeconomic and cultural environment or situation (ICA-ILO, 2001; Mollel \& Mtenga, 2000). Gender division of labour in rural Ethiopia varies in terms of farming systems, cultural settings, location and the different wealth categories (Abera et al., 2006; Mollel \& Mtenga 2000). Gender roles in the country also vary according to ethnicity, income, and status (Ogato et al., 2009).

Agriculture is an engine of economic growth and provides the basis for most livelihoods in developing countries (World Bank, 2007). Women are a significant portion of the agricultural labor force, constituting an average of 43 percent in developing countries, with ranges from about 20 percent in Latin America to 50 percent in Eastern Asia and sub-Saharan Africa. Women are the majority of the agricultural labor force in over 30 countries (FAO, 2011). They are critical to building strong agriculture sectors that can serve as the foundation for long-term food security, poverty reduction, and economic growth.

Women play a vital role in advancing agricultural development and food security (FAO, 2011). They participate in many aspects of rural life - in paid employment, trade and marketing, as well as many unpaid activities, such as tending to crops and animals, collecting water and wood for fuel, and caring for family members. Women also manage household consumption and food preparation. But women face many constraints in the multiple activities they pursue - less land ownership, access to credit, extension and other services, and ability to hire labor (Doss et al., 2008). Too often, these constraints as well as women's current and potential contributions to agricultural production go unrecognized.

There have been few studies concerning women in Ethiopia, but many observers have commented on the physical hardship that Ethiopian women experience throughout their lives. Such hardship involves carrying firewood and water over long distances on a daily basis, grinding corn manually, working in the homestead, raising children, and cooking. Ethiopian women traditionally have suffered sociocultural and economic discrimination and have had fewer opportunities than men for personal growth, education, and employment. Over 85 per cent of Ethiopian women reside in rural areas, where peasant families are engaged primarily in subsistence agriculture. Rural women are integrated into the predominantly agricultural rural economy, which is labour intensive and exacts a heavy physical toll on all, including children. Land reform did not change their subordinate status, which was based on deep-rooted traditional values and beliefs. An improvement in economic conditions would improve the standard of living of women, but real change would require a transformation of the attitudes regarding women (Aregu et al., 2011). Even though Ethiopian women make a significant contribution to the agricultural sector, as women in others parts of the developing world, they usually have no or limited access to and control over important agricultural resources such as land, livestock, farm implements, capital, knowledge and information, which constrains their role in and contribution to production and marketing of agricultural commodities. 
In Ethiopia, as in many other African countries, there is a sharp contrast between men and women in terms of ownership of assets (land and livestock) and decision-making power, access to information, training, mass media and markets. Although customary laws afford some level of access to productive resources to women in certain ethnic groups (Flintan et al., 2008), men are, by and large, relatively better equipped to take advantage of new market opportunities and to adopt new production methods. The existing low level of consciousness about the roles women play in the development of Ethiopia; the deep-rooted cultural beliefs and traditional practices that prevent women from playing their full roles in the development process of the country; lack of appropriate technology to reduce the workload of women; shortage of properly qualified female development agents to understand, motivate and empower rural women by eliminating the major constraints hindering their progress (United Nations, 2002) motivated to conduct this research in the study area. Therefore, this study was conducted with the objective of assessing gender roles, major constraints that affect participation of gender in potato production and decision making habit of gender in the study area.

\subsection{Statement of Problem}

In most societies men's roles in agricultural activities is understood to be directed and clear. However women's role in agriculture is not clearly recognized (Messay, 2012). Hence a clear picture of women's of participation in agriculture is needed. Women usually have limited accesses to resources and opportunities and their productivity remains low relative to their potential. Due to lack of awareness in our society women's role has not been recognized noted that we live in a society in which there is substantial level of gender inequality. In terms of ownership of property, the women in this country have no equal right as men. In addition, the dominance of men in various income generating activities affects highly the economic empowerment of women. Women play important roles to help their family in particular and their community in general in sewing their food demand, in the world. But the most surprising thing is that the community has not significantly under stood the effort that they exert in the last several years. Woman are involved in agricultural and rural development representing more than half of the labor required to produce food consumed in developing countries (Messay, 2012).

Ethiopia women have played a traditional role of motherhood and home maker in both rural and areas. However, their work has never been limited to the household and the family. Ethiopia women are actively involved in all aspects of their social life. Women are both producers and procreators and they are active participant in the social and cultural activities of the community. However, the important roles they play have not always been recognized. Without, equal opportunities, they have legged behind men in all fields of self advancement. Economic development is unthinkable without women participation; however, because their participation in the economy has not been valued Ethiopian women have not received even their share of the nation wealth (The Ethiopian Herald, 2004). Woman's productivity is predominated in the processing and marketing of food in rearing, and food processing and industries. In rural areas, women are engaged in a wide variety of economic activities including the constriction of houses, land cultivating and harvesting, and food storage and 
marketing (Messay, 2012). However, women's work in the agricultural sector has often been erroneously documented as marginal and they have been considered more as consumer than producers. Women have secondary status within the family and in the society, which is why they get little credit for their productivity. Hence, women continue to be regarded as an appendage to the family and as consumer but not as producers. Therefore, this study focused on assessing gender role in potato production and marketing.

\subsection{Objective of the Study}

The overall objective of this study is to assess the role of gender in potato production and marketing, challenges of gender participation on potato production and marketing and the decision making habit of gender on potato production and marketing in the study area.

\section{Materials and Methods}

\subsection{Description of Study Area}

This study was conducted in Southwestern Ethiopia, Masha district of Sheka zone. Masha is one of three districts in Sheka zone of Southern Nation Nationalities and Peoples Region (SNNPR), which is located at $677 \mathrm{~km}$ to southwest of Addis Ababa. Sheka zone is known by its dense forest coverage and the agro-ecology is $70 \%$ mid altitude, $20 \%$ high altitude and 10\% low altitudes. The zone composes three Districts Yeki, Andracha and Masha Districts. Its altitude ranges from 950 to 3300 meter above sea level. Mean rain fall level is more than 2000mm. Regarding rain fall distribution, high rain fall at (June, July, August, September), medium at (October, November, March), low at (April, May) and little/no at( December and January).Major crops grown in the area are Enset, sorghum, maize, coffee, potato, field pea, Fava bean, wheat, barley, haricot bean and teff. Agricultural farming system is Enset production based farming system. Total land coverage of the area is 217527.15 hectare and from this $26 \%$ cultivation, $41.3 \%$ plantations, $2.24 \%$ pasture, $8.96 \%$ cultivable and $3.5 \%$ uncultivable land. The area was selected for this study due to exceptionally high potential for potato production in the southwestern part of Ethiopia. The district is composed of 19 rural kebeles among these the study was conducted in 3 kebeles viz., Gatimo, Atiso and Shibo as indicated in Figure 1.

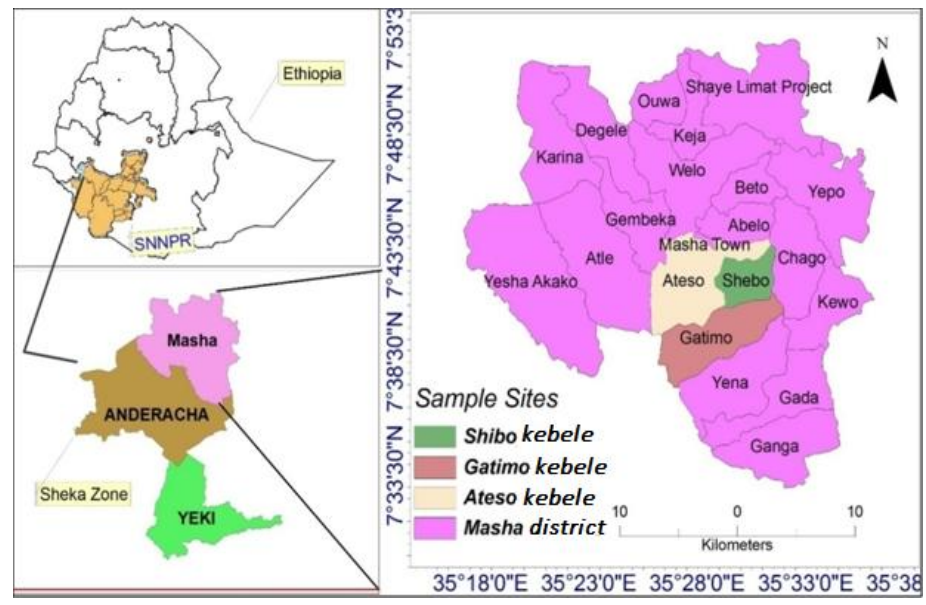

Figure 1. Study area map 


\subsection{Data Source and Instruments}

In this study both primary and secondary data sources were used. Different approaches of primary data collection methods were used. This includes survey, focus group discussions, key informant interviews, field observations and market assessments. Individuals from Agricultural development and cooperative offices as well as the local people who have knowledge and experience about potato production and marketing were selected as key informants and interviewed on the issues related to potato production and marketing.

\subsection{Sampling Procedure}

In this study, three-stage sampling technique was used. In the first stage high quantity potato producing district was purposively selected. At the second stage, among the 19 rural Kebeles of district, 3 Kebeles were again purposively selected based on the intensity of production and marketing of potato. In the third stage, household heads producing potato were selected randomly from the total potato producers from three Kebeles. The sample size was determined by proportional to total population within three kebeles. Thus, using the total potato producers household list 193 producers were selected proportionally to total population of three kebeles.

Table 1. Sample size of producers

\begin{tabular}{lcccc}
\hline Kebeles & Total number of potato producers (population) & Sample size & Percent & Cum. \\
\hline Gatimo & 116 & 60 & 31.09 & 31.09 \\
Shibo & 108 & 56 & 29.02 & 60.1 \\
Atiso & 149 & 77 & 39.9 & 100 \\
\hline Total & 373 & 193 & 100 & \\
\hline
\end{tabular}

Source: own survey, 2017.

\section{Results and Discussions}

\subsection{Sociodemographic Charactersitics of Respondents}

Age is among the factors that are frequently used in smallholder agriculture studies. It has implications for labor availability in farm activities, farming experience, agricultural technology adoption decisions, and productive efficiency (Leulsegged et al., 2015). The average age of interviewed male respondents was 37.71053 years while female's average age was 34.66667 years old. The result of this study showed that male respondents are older than females by three years (table 2). This result contradicts the finding of Leulsegged et al. (2015) and Holden et al. (2011). Regarding to the family size male respondents has higher household size than female respondents. Ethiopian female holders also tend to have smaller household sizes than do male holders. Nationally, on average, female holders have 1.6 fewer household members than their male counterparts (Leulsegged et al., 2015). This has important implications for household labor availability and access to labor through social arrangements, 
which is an important source of agricultural labor in rural Ethiopia. It is generally believed that the larger the family size the more labour available in the household, other things remains constant. Female respondents are also less educated, on average, than male respondents. This result is also in line with the finding of Leulsegged et al. (2015). There is also a big difference in the experience in Agricultural production of male and female respondents. Male respondents were higher in experience than females. Regarding to distance from nearest market, female respondents had higher distance to the nearest market center than male respondents. This variable is a good indicator to market access. Therefore we can conclude that male respondents had mare market access than females. When we compare distance from nearest farming center also female respondents had smaller distance from farmers training center than male respondents.

Table 2. Demographic characteristics of respondents for continuous variables

\begin{tabular}{|l|c|c|}
\hline & \multicolumn{2}{|c|}{ Mean } \\
\hline Age & Male & female \\
\hline Family size & $37.71053(10.12386)$ & $34.66667(4.618802)$ \\
\hline Education_level & $6.073684(2.071434)$ & $5.333333(.5773503)$ \\
\hline Experience & $5.463158(3.154942)$ & $1.333333(1.154701)$ \\
\hline Distance from the market & $7.094737(4.332903)$ & $3.666667(4.618802)$ \\
\hline Distance from farmers training center & $5.463158(2.724805)$ & $8(1.732051)$ \\
\hline Total farming land & $3.310526(2.003375)$ & $2.666667(.5773503)$ \\
\hline Area allocated for potato production & $3.168211(1.948268)$ & $2.166667(1.154701)$ \\
\hline Total output & $0.843526(1.261939)$ & $0.208333(.1443376)$ \\
\hline Quantity sold & $43.15789(27.20131)$ & $22.66667(13.27906)$ \\
\hline
\end{tabular}

Source: Own survey, 2016.

Females had smaller land holding than male respondents. This result is in line with the finding of (Leulsegged et al., 2015) which showed that the size of land managed by female landholders is, on average, 43 percent smaller than the size of land managed by their male counterparts. In Ethiopia, if the female holder is a household head due to her husband's death, she can have relatively small land holdings because, when the husband dies, the widow is supposed to transfer half of the jointly owned land to any of his eligible family members to inherit (Holden et al., 2011). The smaller size of land managed by female landholders could be attributed to the way in which many women become holders as well as household heads. Hence, the widow's farm size will be half the size of her former husband's holdings. In addition, female holders are relatively less likely to rent land than are male holders, which is likely due to barriers to their access and use of other related inputs required to manage land (Holden et al., 2011). And also male respondents had higher managed land for potato production than female respondents. This indicates that male holders have relatively better 
access to land than their female counterparts.

From the total respondents only $2 \%$ of respondents were females and the rest respondents were male. From total respondents about $96.4 \%$ of studied respondents were married, where the remaining were not married. Only half of producers had access to market information. Form the total respondents $2.6 \%$ of respondents had access to credit while the rest $97.4 \%$ of respondents had no access of credit. Concerning other services, about $60 \%$ of producers had access to extension.

Table 3. Socioeconomic characteristics of producers (categorical variables)

\begin{tabular}{|l|c|c|c|}
\hline Variables & Description & Frequency & Percent \\
\hline \multirow{2}{*}{ Access to extension service } & Yes & 116 & 60 \\
\cline { 2 - 4 } & No & 77 & 40 \\
\hline \multirow{2}{*}{ Access to market information } & Yes & 96 & 50 \\
\cline { 2 - 4 } & No & 97 & 50 \\
\hline \multirow{2}{*}{ Sex } & Male & 190 & 98 \\
\cline { 2 - 4 } & Female & 3 & 2 \\
\hline \multirow{2}{*}{ Access to credit } & Yes & 5 & 3 \\
\cline { 2 - 4 } & No & 188 & 97 \\
\hline
\end{tabular}

Source: Own survey, 2017.

\subsection{Gender Division of Labour in Potato Production and Marketing}

According to the survey result in the table 4, the gender that participate in seed collection were male only $(2.1 \%)$, women only $(0.5 \%)$, hired labour only $(0.5 \%)$, male and women (33\%),boys and girls (6.9\%), male, women and boys (5.9\%) and All of the household member $(51.1 \%)$. It also indicated that $35.5 \%$ males only, $2 \%$ boys only, $2 \%$ hired labour force only, $17.1 \%$ males and women, $6.7 \%$ males, women and Boys and 36.5\% All household members participate in land preparation for potato production whereas, $2.1 \%$ males only, $1 \%$ women only, $1 \%$ boys only, $20.2 \%$ males and women, $0.5 \%$ boys and girls, $21.2 \%$ males, women and Boys, and 53.9\% All household members performed the task of plantation. The role of women in weeding activity is very large than that of males because $1.6 \%$ males only, $2.6 \%$ women only, $1.6 \%$ boys only, $0.5 \%$ girls only, $17.6 \%$ both males and women, $7.8 \%$ both boys and girls, $21.1 \%$ males, women and boys and 53.9\% All household members participated in weeding activity of potato crop. The category of respondents that participate in cultivation of potato crop was $24.4 \%$ males only, $3.1 \%$ women, $1 \%$ boys only, $1.6 \%$ hired labour, $19.2 \%$ males and women, $1 \%$ boys and girls,9.3\% males, women and boys together, and $40.4 \%$ of All household members. The study conducted by IPMS in Alaba special woreda indicated that men and women share the workload in haricot bean production. Men are more responsible for land preparation, tillage, seed selection and sowing. Women are also involved in sowing seeds but not in seed selection because they lack the knowledge and skill; they also support the men during land preparation and tillage. Women are more responsible for 
threshing, winnowing and storing. Both are involved in weeding, harvesting and day-to-day management (Lemlem et al., 2010). Men are typically responsible for the heavier manual tasks in crop production such as land preparation and tillage with oxen. Men play a dominant role in seed selection, reflecting their better access to information. They also perform jobs of broadcasting seed and fertilizer. Men are usually responsible for threshing and winnowing cereal crops Women are often involved with activities that require dexterity and attention to detail, such as raising seedlings in nurseries, transplanting and weeding. They are also involved with activities closely associated with their household responsibilities, such as storage, processing and adding value (Aregu et al., 2011).

Table 4. Gender role in potato production and marketing

\begin{tabular}{|l|c|c|c|c|c|c|c|c|c|}
\hline Activity & Men & Women & Boys & Girls & $\begin{array}{c}\text { Hired } \\
\text { labour }\end{array}$ & $\begin{array}{c}\text { Men \& } \\
\text { Women }\end{array}$ & $\begin{array}{c}\text { Boy } \\
\& \\
\text { Girl }\end{array}$ & $\begin{array}{c}\text { Men, } \\
\text { Women } \\
\& \text { Boy }\end{array}$ & $\begin{array}{c}\text { All } \\
\text { family } \\
\text { member }\end{array}$ \\
\hline $\begin{array}{l}\text { Seed } \\
\text { collection }\end{array}$ & $2.10 \%$ & $0.50 \%$ & & & $0.50 \%$ & $33.00 \%$ & $6.90 \%$ & $5.90 \%$ & $51.10 \%$ \\
\hline $\begin{array}{l}\text { Land } \\
\text { preparation }\end{array}$ & $35.70 \%$ & & $2.00 \%$ & & $2.00 \%$ & $17.10 \%$ & & $6.70 \%$ & $36.50 \%$ \\
\hline Planting & $2.10 \%$ & $1.00 \%$ & $1.00 \%$ & & & $20.20 \%$ & $0.50 \%$ & $21.20 \%$ & $53.90 \%$ \\
\hline Weeding & $1.60 \%$ & $2.60 \%$ & $1.60 \%$ & $0.50 \%$ & & $17.60 \%$ & $7.80 \%$ & $21.80 \%$ & $46.60 \%$ \\
\hline Cultivation & $24.40 \%$ & $3.10 \%$ & $1.00 \%$ & & $1.60 \%$ & $19.20 \%$ & $1.00 \%$ & $9.30 \%$ & $40.40 \%$ \\
\hline Harvesting & $2.10 \%$ & $1.60 \%$ & $1.00 \%$ & $1.60 \%$ & $1.00 \%$ & $16.60 \%$ & $2.10 \%$ & $16.10 \%$ & $58.00 \%$ \\
\hline Transporting & $2.10 \%$ & $1.60 \%$ & $1.00 \%$ & $1.00 \%$ & $0.50 \%$ & $19.20 \%$ & $5.70 \%$ & $12.40 \%$ & $56.50 \%$ \\
\hline Marketing & $17.10 \%$ & $20.70 \%$ & & $0.50 \%$ & & $42.00 \%$ & $5.70 \%$ & & $14.00 \%$ \\
\hline
\end{tabular}

In harvesting activity also $2.1 \%$ males only, $1.6 \%$ women only, $1 \%$ boys only, $1.6 \%$ girls only, $1 \%$ hired labour, $16.6 \%$ male and women, $2.1 \%$ boys and girl,16.1\% male, women and boys, and $58 \%$ of All household members participated in the study area. And 2.1\% males only, $1.6 \%$ women only, $1 \%$ boys only, $1 \%$ girls only, $0.5 \%$ hired labour, $19.2 \%$ males and women, $5.7 \%$ boys and girls, $12.4 \%$ males, women and boys, and $56.5 \%$ of All household members transport potato from harvested land to home of the farmer. In marketing of potato $17.1 \%$ males only, $20.7 \%$ women only, $0.5 \%$ girls only, $42 \%$ males and women, $5.7 \%$ boys and girls, and $14 \%$ of all household members participated. The role of women in marketing of potato was very huge because they highly participated in retailing activity. Women are twice as likely as men to be involved in agriculture related activities (Odame et al., 2002). Tsegaye (1997) asserts that Ethiopian rural women participate in various farm activities such as field preparation, planting, weeding, manuring, harvesting, transporting, threshing, seed selection/sorting, storage, processing and marketing agricultural produce. The findings of this paper confirmed that females' contribution in potato production was significantly lower than that of males. However, the percentage share of female holders who participated in cereal production is, on average, lower than the percentage of male holders who engage in this 
activity. In particular, the proportion of female holders who participate in teff production is about 14 percentage points lower than for male holders. This may be attributed to higher labor requirements for teff, including land preparation, weed management, and other agronomic practices. Nationally, the percentage of female holders who participated in each type of pulse production is, on average, lower than the percentage of male holders who engaged in the same activity. Nationally, the percentage share of female holders who participated in each type of root crop production is lower than the percentage share of male holders (Leulsegged et al., 2015). Ogato et al., 2009 confirmed that females contribution in reproductive, productive and community work is significantly higher that of males.

Even though females performed various activities for potato production and marketing in the study area, they are not decision maker regarding production and marketing related processes. Majority of activities carried out regarding potato production $(51.30 \%)$ as well as marketing $(51.80 \%)$ were decided by male-parent only, however, decisions related to quantity and mode of potato consumption at home dominantly decided by male -parent $(76.6 \%)$ and followed by female household $(19.10 \%)$. The productive and reproductive roles of females in society, termed as "double-day" roles, results in a heavier workload for females than males, although this also depends on social class, age or ethnicity group (Peter, 2006). Females in female headed households have a heavier workload than females in male-headed households because of the additional responsibility of household headship compared to women in male-headed households. However, it is almost impossible to draw general conclusions about the division of labour and the share of the benefits between women and men. There are significant interand intra-regional variations. For example, pepper is exclusively a women's crop in Fogera, yet men dominate production in Alaba. Similarly, while men dominate vegetable activities in Atsbi-Wemberta, the activity and benefits are shared in Bure. In Gomma, men dominate the benefit of fruit production in one kebeles while women dominate it in the others (Lemlem et al., 2010).

\subsection{Decision Making Habits in Potato Production and Marketing}

From the result of this study it is identified that though few mutual decision between both genders men had upper hand in all decisions regarding potato production and marketing. Lack of decision making on potato production and marketing as well as lack control over potato income and other assets inclined contribution of production to male individuals than females.

Table 5. Decision making in potato production and marketing

\begin{tabular}{|l|c|c|c|c|c|c|c|}
\hline Type of Decision & Men & Women & $\begin{array}{c}\text { Men \& } \\
\text { women }\end{array}$ & $\begin{array}{c}\text { Men, Women } \\
\text { and Girl }\end{array}$ & $\begin{array}{c}\text { Boy and } \\
\text { Girl }\end{array}$ & $\begin{array}{c}\text { All family } \\
\text { members }\end{array}$ & Total \\
\hline Production decision & $51.3 \%$ & & $37.8 \%$ & $1.0 \%$ & $0.5 \%$ & $9.4 \%$ & $100 \%$ \\
\hline Seed collection decision & $51.3 \%$ & & $37.3 \%$ & $1.0 \%$ & $2.6 \%$ & $7.8 \%$ & $100 \%$ \\
\hline Marketing decision & $51.8 \%$ & $1.0 \%$ & $36.3 \%$ & $1.0 \%$ & $1.0 \%$ & $8.9 \%$ & $100 \%$ \\
\hline Consumption decision & $39.1 \%$ & $9.4 \%$ & $40.6 \%$ & & & $10.9 \%$ & $100 \%$ \\
\hline
\end{tabular}


Decisions about enterprise mix and technology adoption, including seed selection, are mainly taken by men and in some cases, are negotiated between husbands and wives. The general trend appears to be one of male-dominated decisions in rich and middle households, and joint decisions in poor households. Only in female-headed households do women control the decisions; yet this still tends to be in consultation with their male relatives. It was noted that even though men appear to be in control of decision-making, they usually consult their wives and women have a strong influence on the outcome (Lemlem et al., 2010).

\subsection{Challenges of Gender in Potato Production}

Livelihood assets refer to both tangible and intangible productive resources, and they can be categorized as human capital (e.g. education and skills), natural capital (e.g. land and water), financial capital (e.g. savings and credit), physical capital (e.g. agricultural equipment), social capital (e.g. membership in organizations), and political capital (e.g. effective participation in governance) (Meinzen et al., 2011). These assets enable people to engage in different livelihood activities to achieve their livelihood goals. The livelihood strategies and welfare status of individuals have direct and indirect links with access to, ownership of, control over, and use of these livelihood assets (DFID, 2001). The degree of access to and control over resources within a society play significant roles in differentiating members of a society in policy and decision making processes (Zenebe, 2005). Generally there is an imbalance between workloads and share in the benefits of production. Men tend to control the income from many crop and livestock commodities where they dominate or share the workload such as field crops, vegetables, tree crops and large ruminants.

Table 6. Challenges that hinder gender participation in potato production

\begin{tabular}{|l|c|}
\hline Challenges & Percentage \\
\hline access and control over assets & $19.2 \%$ \\
\hline lack of control of income & $30.6 \%$ \\
\hline lack of land & $6.7 \%$ \\
\hline lack of decision on potato production & $39.9 \%$ \\
\hline Nothing & $3.6 \%$ \\
\hline Total & $100 \%$ \\
\hline
\end{tabular}

According to the survey result, one of challenges that hinder women participation in potato production was lack of lack of land (6.7\%). This indicates that male holders have relatively better access to land than their female counterparts (Leulsegged et al., 2015). Some statistics, for example indicate that women worldwide own only 2 per cent of the land, receive only 5 per cent of all agricultural extension services and constitute only 7-11 percent of the beneficiaries of credit programs (Siwingwa, 2005). Even though women play a significant role in agricultural productivity, carrying out an estimated $40 \%$ to $60 \%$ of all agricultural labour (World Bank, 2008a), they suffer from unequal access to resources and capacity-building opportunities on a number of levels. Women face many constraints in the 
multiple activities they pursue - less land ownership, access to credit, extension and other services, and ability to hire labor. Too often, these constraints as well as women's current and potential contributions to agricultural production go unrecognized (Doss et al., 2008). Women are just as efficient agricultural producers as men and can achieve similar yields when given equal access to resources, including training and services (USAID, 2011). For example, in Kenya, researchers found that women could increase their crop yields by approximately 20 percent if given the same access to the same resources as men (Saito et al., 1994). In Burkina Faso, it has been estimated that overall household production could increase by about six percent by more equitably distributing fertilizer and labor between male and female-farmed plots (Udry, Christopher, 1996). The Food and Agriculture Organization of the United Nations (FAO) estimates that if women had the same access to productive resources as men, they could increase yields on their farms by 20-30 percent. This increase could raise total agricultural output in developing countries by 2.5-4 percent and reduce the number of hungry people in the world by 12-17 percent, up to 150 million people (FAO, 2011). 19.2\% respondents responded that women have lack of access to and control over assets. In general, however it can be argued that lack of access to and control over resources by African women in particular is the single most important cause of gender inequality in the continent (Tamale, 2005). In addition, it is revealed in many empirical studies that women's lack of access to and control over resources reduce their net productivity (Zenebe, 2005, Ishengoma, 2005). In rural Ethiopia, like other developing countries the great majority of women do not have access to and control over resources. Even women with access to resources do not have actual control over the resource (Zenebe, 2005). The descriptive result indicated that $30.6 \%$ of respondents showed that there is lack of income control for women's in the study area. Women may sell up to $20 \mathrm{~kg}$ per season, often in small amounts when cash is needed at home, while men sell between 100-600 kg and control the income. Women have control over the beans left at home for consumption. The inequity is that while the workload is shared between men and women at many stages of haricot bean production, the right to access the benefits is very limited for women (Lemlem et al., 2010).

\section{Conclusion}

Men are more responsible for land preparation, tillage, seed selection and sowing. Women are also involved in sowing seeds but not in seed selection because they lack the knowledge and skill; they also support the men during land preparation and tillage. Women are more responsible for threshing, winnowing and storing. Both are involved in weeding, harvesting and day-to-day management. Men are typically responsible for the heavier manual tasks in crop production such as land preparation and tillage with oxen. Men play a dominant role in seed selection, reflecting their better access to information. They also perform jobs of broadcasting seed and fertilizer. Men are usually responsible for threshing and winnowing cereal crops Women are often involved with activities that require dexterity and attention to detail, such as raising seedlings in nurseries, transplanting and weeding. They are also involved with activities closely associated with their household responsibilities, such as storage, processing and adding value.

Even though females performed various activities for potato production and marketing in the 
study area, they are not decision maker regarding production and marketing related processes. Majority of activities carried out regarding potato production $(51.30 \%)$ as well as marketing $(51.80 \%)$ were decided by male-parent only, however, decisions related to quantity and mode of potato consumption at home dominantly decided by male -parent $(76.6 \%)$ and followed by female household (19.10\%).

Generally there is an imbalance between workloads and share in the benefits of production. Men tend to control the income from many crop and livestock commodities where they dominate or share the workload such as field crops, vegetables, tree crops and large ruminants. Therefore, focus should be taken in Economic empowerment of gender in agricultural production and marketing activity. However, women's role in the economy has often been underestimated, and their work in agriculture has been invisible for a long time. Finally this paper presents the result of Masha Woreda according to the respondents result. Though women contribute a significant amount to the agricultural labour force yet they are not updated regularly about new farming practices and have few opportunities to develop their skills base. In turn, this will affect their productivity and their ability to innovate and fulfill their productive potential. Therefore it is better to designing development interventions for supporting market-oriented agricultural development by accessing technologies and services.

\section{References}

Abera, G., Gudeta, H., Belissa, M., Shale, G., Degefe, A., \& Akassa, B. (2006). Gender Based Roles and Resource Use Right in Potato Production and Marketing System: The Case of Some Districts in Oromia, Ethiopia. A Research Report. Addis Ababa: OARI and OSSREA.

ACDI/VOCA. (2013). Cooperatives hold economic promise for women in Ethiopia. Feed the future program bolsters cooperatives as empowerment strategy for women.

Aregu, L., Puskur, R., Renard, G., Hoekstra, D., \& MacMillan, S. (2011). GenderEmpowering women through value chain development: Good practices and lessons from IPMS experiences. Nairobi, Kenya: ILRI.

Bill \& Melinda Gates Foundation. (2010). Accelerating Ethiopian agriculture development for growth, food security, and equity.

DFID (Department for International Development). (2001). Sustainable Livelihoods Guidance Sheets. London: FID.

Doss, C., Caren, G., \& Carmen, D. D. (2008). Gender and Asset Ownership: A Guide to Collecting Individual-Level Data. Policy Research Working Paper 4704. Washington, DC: World Bank.

FAO. (2011a). The Food and Agriculture Organization of the United Nations.

FAO. (2011b). The State of Food and Agriculture: Women in Agriculture: Closing the Gender Gap for Development. Food and Agriculture Organization of the United Nations, Rome, Italy.

Food and Agriculture Organization of the United Nations. (2011). The State of Food and 
Agriculture 2010-11: Women in Agriculture. Rome: FAO.

Holden, S. T., Deininger, K., \& Ghebru. H. (2011). Tenure Insecurity, Gender, Low-Cost Land Certification and Land Rental Market Participation in Ethiopia. Journal of Development Studies, 37(1), 31-47. https://doi.org/10.1080/00220381003706460

ICA-ILO. (2001). Gender Issues in Cooperatives: An ICAILO Perspective.

Ishengoma, C. G. (2004). Accessibility of Resources by Gender: The Case of Monogoro Region in Tanzania. In Elizabeth Annan-You, et al. (Eds.), Gender, Economies and Entitlement in Africa (pp. 53-66). CODESRIA Gender Series 2. Council for the Development of Social Science Research in Africa. Senegal; Dakar.

Lemlem, A., Bishop-Sambrook, C., Puskur, R., \& Ephrem, T. (2010). Opportunities for promoting gender equality in rural Ethiopia through the commercialization of agriculture. IPMS (Improving Productivity and Market Success) of Ethiopian Farmers Project Working Paper 18. ILRI (International Livestock Research Institute), Nairobi, Kenya.

Leulsegged, K., Gashaw, T., James, W., \& Caitlin, K. (2015). Patterns of Agricultural Production among Male and Female Holders: Evidence from Agricultural Sample Surveys in Ethiopia. International Food Policy Research Institute (IFPRI) Addis Ababa, Ethiopia.

Meinzen-Dick, R., Johnson, N., Quisumbing, A., Njuki, J., Behrman, J., Rubin, D. et al. (2011). Gender, Assets, and Agricultural Development Programs: A Conceptual Framework. Washington, DC: International Food Policy Research Institute.

Messay. (2012). An assessment on the role of women in agriculture in southern nation nationality people's region: The case of halaba special woreda, Ethiopia. Submitted to indira Gandhi national open University /ignou/ in partial fulfilament of the requirement for master of arts in rural development.

Saito, K., Hailu, M., \& Daphne, S. (1994). Raising the Productivity of Women Farmers in Sub-Saharan Africa (Discussion Paper 230). Washington, D.C.: World Bank. https://doi.org/10.1596/0-8213-2749-6

Siwingwa, N. (2005). Gender and Food Security. In N. Tanzarn (Ed.), Gender in Agriculture and Technology (Gendered World Series, pp. 205-209). Women and Gender Studies, Fountain: Kampala.

Tamale, S. (2004). Gender Trauma in Africa: Enhancing Women's Links to Resources. In Elizabeth Annan-You, et al. (Eds.), Gender, Economies and Entitlement in Africa (CODESRIA Gender Series 2, pp. 18-31). Council for the Development of Social Science Research in Africa. Senegal; Dakar. https://doi.org/10.1017/S0021855304481030

The Ethiopian Herald. (2004). Focus on women. The Ethiopian Herald, Ilx(227). addis ababa, brianna slam printing press.

Udry, C. (1996). Gender, Agricultural Production, and the Theory of the Household. Journal of Political Economy, 104, 1010-1046. https://doi.org/10.1086/262050 


\section{Macrothink}

World Journal of Business and Management

ISSN 2377-4622

2018, Vol. 4, No. 2

USAID. (2011). Women \& Agriculture: Improving Global Food Security. Produced in coordination with the Bureau of Public Affairs, U.S. Department of State.

World Bank. (2007). World Development Report 2008: Agriculture for Development. Washington, DC: World Bank. https://doi.org/10.1596/978-0-8213-6807-7

Zenebe, N. B. (2004). Trajectories of Women, Environmental Degradation and Scarcity: Examining Access to and Control over Resources in Ethiopia. In Elizabeth Annan-You, et al. (Eds.), Gender, Economies and Entitlement in Africa (CODESRIA Gender Series 2, 67-86). Council for the Development of Social Science Research in Africa. Senegal; Dakar.

\section{Copyright Disclaimer}

Copyright for this article is retained by the author(s), with first publication rights granted to the journal.

This is an open-access article distributed under the terms and conditions of the Creative Commons Attribution license (http://creativecommons.org/licenses/by/3.0/). 